


\section{UCLA FORUM IN MEDICAL SCIENCES}

Victor E. HaLl, Editor

Martha Bascopé-Espada, Assistant Editor

\author{
Forrest H. Adams \\ Mary A. B. Brazier \\ Carmine D. Clemente \\ Louise M. Darling \\ Morton I. Grossman
}

EDITORIAL BOARD

William P. Longmire

H. W. Magoun

C. D. O'Malley

Sidney Roberts

Emil L. Smith

Reidar F. Sognnaes 
THE INTERNEURON 



\section{UCLA FORUM IN MEDICAL SCIENCES NUMBER 11}

\section{THE INTERNEURON}

Proceedings of a Conference held September, 1967

Sponsored by the Brain Research Institute, University of California, Los Angeles

EDITOR

MARY A. B. BRAZIER

UNIVERSITY OF CALIFORNIA PRESS

BERKELEY AND LOS ANGELES

1969 


\section{EDITORIAL NOTE}

The present volume contains the proceedings of the first in a series of conferences on Neural Interaction, organized by Arnold B. Scheibel, Carmine D. Clemente, Mary A. B. Brazier and John D. French of the Brain Research Institute, UCLA School of Medicine.

Acknowledgement for the support of this conference is owed to the following: Abbott Laboratories; Hoffmann-LaRoche; Merck Sharp \& Dohme; Sandoz Foundation; Schering Corporation; Smith, Kline \& French; E. R. Squibb \& Sons, Upjohn Company and Wallace Laboratories.

\footnotetext{
CITATION FORM
}

Brazier, M. A. B. (Ed.), The Interneuron. UCLA Forum Med. Sci. No. 11, Univ. of California Press, Los Angeles, 1969

\footnotetext{
University of California Press

Berkeley and Los Angeles, California

University of California Press, Ltd.

London, England
}

(C) 1969 by The Regents of the University of California Library of Congress Catalog Card Number: 69-16504

Printed in the United States of America 


\title{
PARTICIPANTS IN THE CONFERENCE
}

\author{
ARNold B. Scheibel, Chairman \\ Brain Research Institute,UCLA School of Medicine \\ Los Angeles, California
}

Mary A. B. Brazier, Editor

Brain Research Institute, University of California

Los Angeles, California

\author{
W. Ross AdEY \\ Brain Research Institute, UCLA School of Medicine \\ Los Angeles, California
}
Per ANDERsen
Neurophysiological Institute, University of Oslo
Oslo, Norway

Theodor W. Blackstad

Normal-Anatomisk Institut, Aarhus Universitet

Aarhus, Denmark
Theodore H. Bullock
Department of Neurosciences, University of California San Diego
La Jolla, California

Carmine D. Clemente

Department of Anatomy, UCLA School of Medicine

Los Angeles, California

JoHN D. French

Brain Research Institute, UCLA School of Medicine

Los Angeles, California

M. G. F. Fuortes

Laboratory of Neurophysiology

National Institute of Neurological Diseases and Blindness

Bethesda, Maryland 


$$
\begin{gathered}
\text { SusumU Hagrwara } \\
\text { Scripps Institution of Oceanography } \\
\text { University of California San Diego } \\
\text { La Jolla, California }
\end{gathered}
$$

Victor E. HaLL

UCLA Forum in Medical Sciences, UCLA School of Medicine

Los Angeles, California

G. Adruan Horrudge

Gatty Marine Laboratory, University of St. Andrews

Fife, Scotland

Masao Ito

Department of Physiology

University of Tokyo Faculty of Medicine

Tokyo, Japan

ERIC R. KANDEL

Departments of Physiology and Psychiatry

New York University School of Medicine

New York, New York

Donald Kennedy

Department of Biological Sciences, Stanford University

Stanford, California

L. M. H. LARRAMENDI

Department of Anatomy

University of Illinois College of Medicine

Chicago, Illinois

Chan-Nao LiU

Department of Anatomy and Institute of Neurological Sciences

University of Pennsylvania School of Medicine

Philadelphia, Pennsylvania

Rodolfo R. LLINÁs

Department of Neurobiology, Institute for Biomedical Research

American Medical Association-Education and Research Foundation

Chicago, Illinois

ANDERS LUNDBERG

Department of Physiology, University of Göteborg

Göteborg, Sweden

David S. Maxwell

Brain Research Institute, UCLA School of Medicine

Los Angeles, California 
Donald M. Maynard

Department of Zoology, University of Michigan

Ann Arbor, Michigan

Dominick P. PURPura

Department of Anatomy, Albert Einstein College of Medicine

New York, New York

MAdGe E. ScheibEL

Los Angeles, California

JoHN D. SchLAG

Brain Research Institute, UCLA School of Medicine

Los Angeles, California

ROBERT F. SCHMmT

II. Physiologisches Institut, Universität Heidelberg

Heidelberg, Germany

José P. Segundo

Brain Research Institute, UCLA School of Medicine

Los Angeles, California

Sten SKoglund

Department of Anatomy, Karolinska Institutet

Stockholm, Sweden

Wm. ALden SPENCER

Department of Physiology, New York University School of Medicine

New York, New York

Costas Stefanis

Department of Neurology, Athens National University

Athens, Greece

L. TAUC

Laboratoire de Neurophysiologie Cellulaire

Centre d'Etudes de Physiologie Nerveuse

Centre National de la Recherche Scientifique

Paris, France

C. A. G. Wiersma

Biology Division, California Institute of Technology

Pasadena, California

William D. Wirlis, JR.

Department of Anatomy

The University of Texas Southwestern Medical School

Dallas, Texas 



\section{FOREWORD}

Within the frame of contemporary neurophysiology, a conference devoted to the interneuron seems a natural choice. For with the advent of the intracellular microelectrode and recognition of the hyperpolarizing potential as an invariable concomitant, if not causative agent, of postsynaptic inhibition, the presynaptic progenitor of this effect has invariably been identified as a local circuit cell-an interneuron-in the immediate neural environment. A number of different cell families have been implicated in the development of this effect. Internuncials in the intermediate spinal gray, so-called Renshaw cells in the ventral motoneuron pool, basket cells in hippocampus and cerebellum, and stellate cells in neocortex are among those cited. All of these elements are believed to share certain qualities which distinguish them from other neurons. The most important of these are the presumably local (short-axoned) nature of their axonal trajectory, their characteristically intercalated position between long-axoned projection neurons, and their functional capacity for reversing the sign of excitation from facilitation to inhibition.

Selection of elements such as these to serve as chapter and verse for this symposium immediately meets with difficulties. In the first place, their number forms but a fraction of that grand ensemble which rightfully deserves the name of "Interneuron." The definition of Bullock \& Horridge (1) suggests panoramic diversity:

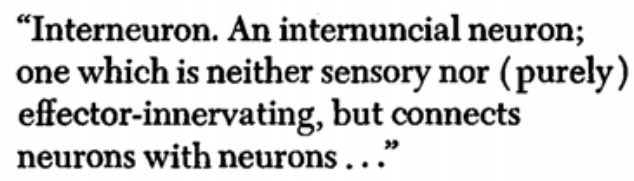

At best, this definition allows us to discard from consideration first order sensory cells, motor neurons, and possibly a few central elements whose peripheral processes run a centrifugal course to control gain levels at the receptor stage. All others, and this must constitute the great majority of elements of the vertebrate nervous system, fall within our category.

For over three quarters of a century the short-axoned (Golgi II) internuncials have seemed to constitute a cell type in search of a function. But, despite the undoubted advantages implicit in their identification as the obligatory, intercalated interneurons mediating inhibition, facts have begun to handle the theory unkindly. For one thing, the Renshaw cell, long considered the paradigm of this type, can no longer be accepted as a short-axoned cell. If indeed there is a special category of spinal neurons responsible for the burst-type firing and IPSPs generated concomitantly in local ipsilateral 
motoneuron populations, structural data demand that they be long-axoned projection cells, similar in all respects to other proprioneurons. The same reservation applies to interneurons more dorsally located and implicated in the generation of primary afferent depolarization. For another, the conceptual restraints imposed by Dale's thesis no longer seem so binding in the light of recent data pointing to mediation of both excitatory and inhibitory functions by the same synaptic substance. With the development of the receptor-mosaic notion of postsynaptic membrane organization, so far shown only in invertebrate material, it is true, the presence of the intercalated sign-reversing cell seems less urgent. In fact, careful study of spinal cord sections with degeneration and Golgi methods now suggests that some loops of known inhibitory function may well be direct rather than interneuronmediated.

With the advantages of exclusivity already under attack, how wide must we enlarge our set so that no worthy candidate is omitted? Following the definition of Bullock and Horridge, all elements beyond the level of the first order sensory cell, and prior to the final common pathway motoneuron must be considered. This includes most spinal neurons, the brain stem axial core, rostral sensory projection systems, the great descending motor paths, pyramidal and extrapyramidal, and all cortical tissue including cerebellum and cerebral hemispheres. Clearly we have invoked a situation demanding consideration, not of a set, but virtually the set of all possible sets.

In similar fashion, the category of functions commonly attributed to interneurons will no longer suffice. In the course of phylogenetic development, only the protozoa, mesozoa, and porifera seem without identifiable nervous systems. The coelenterate nerve nets are made up exclusively of sensory and motor components, fashioned in random nets, some of which are "throughconducting," and others "non-through-conducting." But, even in this primitive matrix, it has been found that activity in the "non-through" may connect directly or progressively to the "through" depending on frequency and (or) repetition rate of the stimulus. Perhaps in this plastic relationship between the two nets where output relates to, but is not precisely the same as, input, we can recognize an Anlage of interneuron function. The next phyletic step, to platyhelminthes presents at once the prospect of a complex ganglionated chain and, with it, of cells whose axonal course is run entirely within ganglia and connectives. Suddenly, many of the familiar characteristics of vertebrate reticular neurons are present including bifurcating axons running long distances rostral and caudal along the chain, and dendrite-like structures immersed in afferent neuropile. And, in successive invertebrate phyla built to this scheme, a bold functional plan emerges. Interneurons are more than the bridge between input and output. They are repositories of the output pattern for which the afferent signal is but the trigger. The sensory input serves only a flip-flop function and the master plan, already coded into the interneuron and its connectivity pattern through the effectors, is ac- 
tivated in invariant form once the sensory input switches to "yes." Here is a class of interneuron activity directly on the route, not just to sign change or relay function but to the most sophisticated strategy-forging levels of cortical operation in the brain.

With progressive enrichment of the set, both in number and in function, it becomes increasingly clear that a symposium on interneurons should properly encompass almost the entire phyletic series, and the vertebrate nervous system from conus to cortex. The range of communications which follows gives substance to this belief.

M. E. and A. B. Scheibel

\section{REFERENCE}

1. Bullock, T. H., and Horridge, G. A., Structure and Function in the Nervous Systems of Invertebrates. Freeman, San Francisco, 1965: p. 1602. 


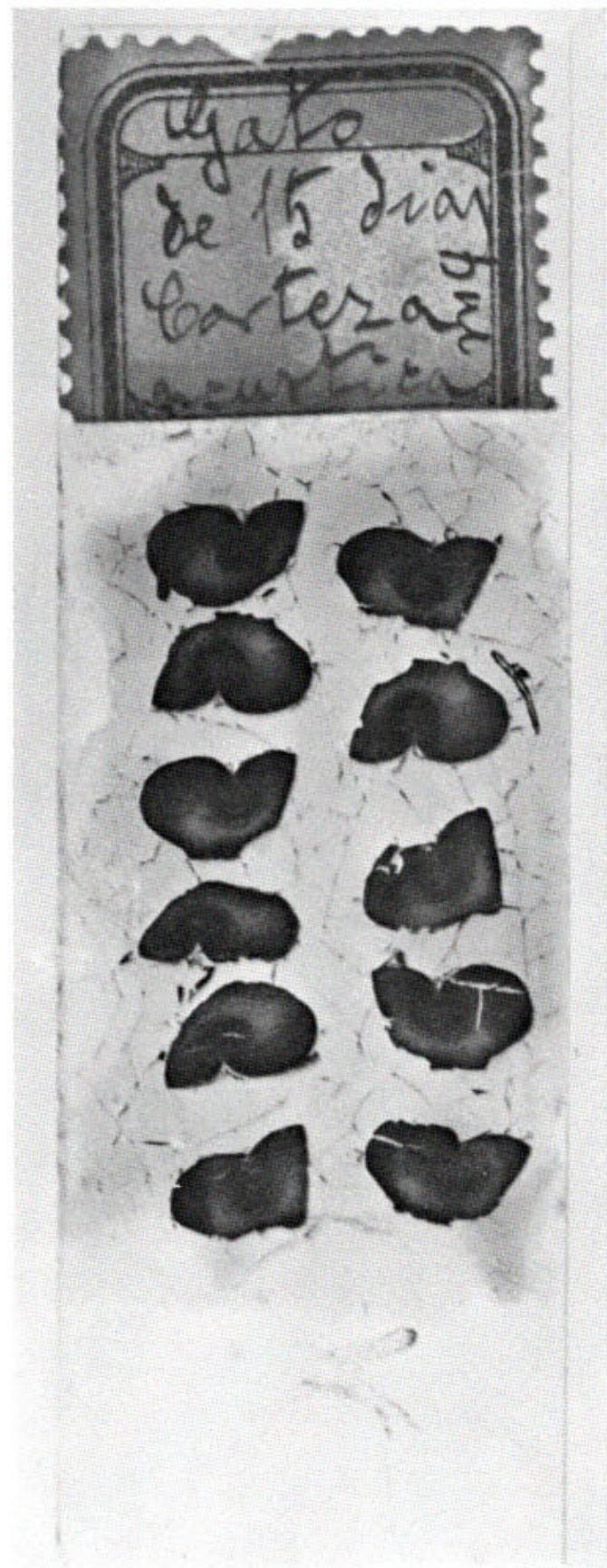

This slide was prepared personally by Santiago Ramón y Cajal and was presented to the Brain Research Institute by Professor Clemente Estable of Montevideo, Uruguay. The sections were impregnated with silver according to the techniques of Golgi and, as can be seen by the label in Cajal's own handwriting, are from a "Cat of 15 days, acoustic cortex". The "bue" is short for "bueno", which Cajal used to label his best preparations. 


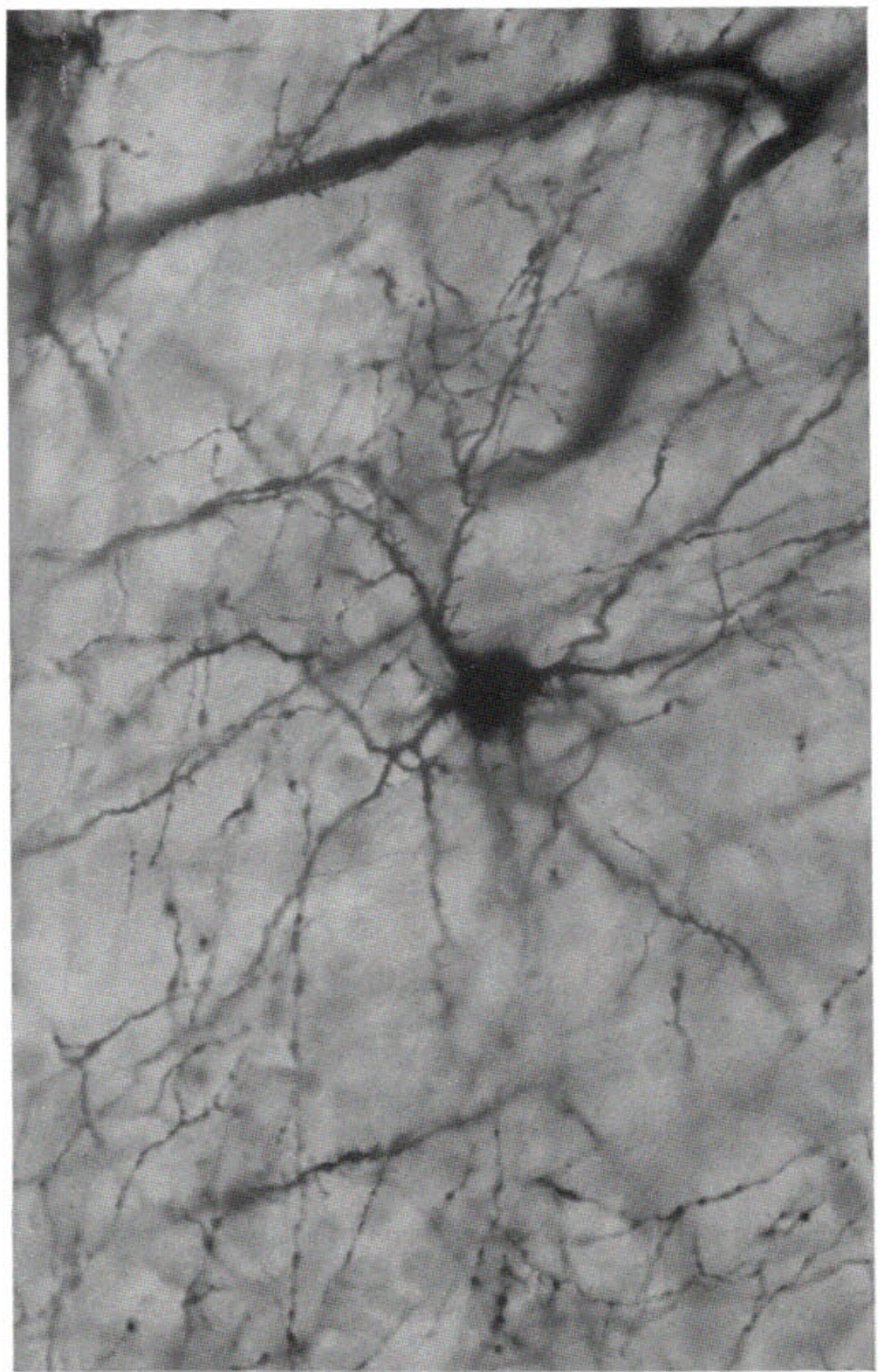

Contemporary photomicrograph made from slide on facing page, showing a cell in the second section in the left column. It shows a short-axoned neuron of the Golgi type at about $\times 740$ magnification. These cells are among those in the cerebral cortex generally considered to be interneurons. 
